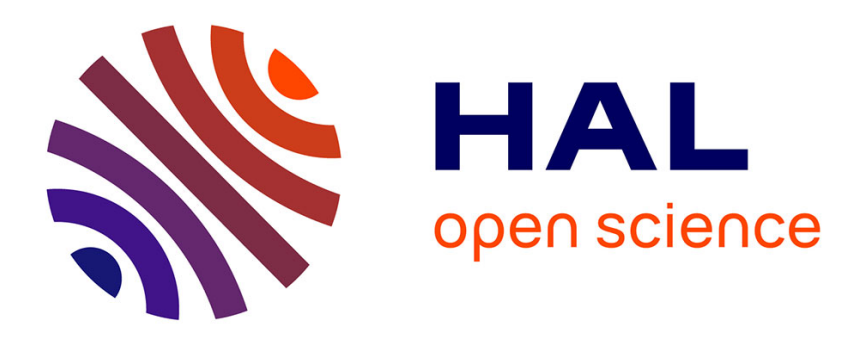

\title{
Complexity in terms of work and organization
}

Christophe Schmitt

\section{To cite this version:}

Christophe Schmitt. Complexity in terms of work and organization. Projectics / Proyéctica / Projectique, 2019, 1 (22), pp.8-9. 10.3917/proj.022.0008 . hal-02365486

\section{HAL Id: hal-02365486 \\ https://hal.univ-lorraine.fr/hal-02365486}

Submitted on 6 Dec 2020

HAL is a multi-disciplinary open access archive for the deposit and dissemination of scientific research documents, whether they are published or not. The documents may come from teaching and research institutions in France or abroad, or from public or private research centers.
L'archive ouverte pluridisciplinaire HAL, est destinée au dépôt et à la diffusion de documents scientifiques de niveau recherche, publiés ou non, émanant des établissements d'enseignement et de recherche français ou étrangers, des laboratoires publics ou privés. 


\section{Editorial}

\section{COMPLEXITY IN TERMS OF WORK AND ORGANIZATION}

\section{Christophe Schmitt}

De Boeck Supérieur | «Projectics / Proyéctica / Projectique »

2019/1 n²2 | pages 8 à 9

ISSN 2031-9703

ISBN 9782807392991

\section{Article disponible en ligne à l'adresse :}

https://www.cairn.info/revue-projectique-2019-1-page-8.htm

Distribution électronique Cairn.info pour De Boeck Supérieur.

(C) De Boeck Supérieur. Tous droits réservés pour tous pays.

La reproduction ou représentation de cet article, notamment par photocopie, n'est autorisée que dans les limites des conditions générales d'utilisation du site ou, le cas échéant, des conditions générales de la licence souscrite par votre établissement. Toute autre reproduction ou représentation, en tout ou partie, sous quelque forme et de quelque manière que ce soit, est interdite sauf accord préalable et écrit de l'éditeur, en dehors des cas prévus par la législation en vigueur en France. Il est précisé que son stockage dans une base de données est également interdit. 


\section{EDITORIAL \\ COMPLEXITY IN TERMS
OF WORK AND ORGANIZATION}

Christophe Schmitt

Professeur et Titulaire de la Chaire Entreprendre, IAE de Metz, Université de Lorraine

In March 2019, has been held in Agadir, Morocco, the Projectics symposium on "Undertake to innovate in training", jointly organized by Collegium Lorraine Management Innovation and Universiapolis of Agadir. Forty people were present from a dozen different countries. The challenge of this international symposium was to examine new ways of addressing the complexity of organizations, in terms of training programs. Nowadays, numerous tools can be used in order to approach training in innovative and different ways. And this holds true even more within more complex organizations, and by means of deploying digital technology, serious games, project and action-based pedagogy, or the competence approach... In this wake, this symposium aimed to present the reasons why training actors have to consider the complexity as far as training programs are concerned, and the new and innovative ways of doing it.

This symposium is the third one, aiming to better grasp the complexity in organizations. The first of one, held in 2017, dealt with the broader theme of "Entrepreneurship and Complexity in Organizations". The second, took place in in 2018, and focused on the theme "Entrepreneurship and the Public Space". The three symposiums were associated with a collective work book, published by IAE Metz School of Management (Université de Lorraine) in 2016 (Growth Publisher), and entitled "The complexity of the action in organizations".

If there is an agreement that complexity is part of everyday activities in organizations, then training should be considered as a vehicle for addressing this complexity, by promoting knowledge, skills, learning, tools... Through this symposium, we sought to encourage transversally the mobilization of various disciplines and actors, involved in the broad field of training, so that they can exchange and benchmark their different experiences. The related contributions succeeded at bridging these experiences and proposing theoretical reflections on the subject. 
Indeed, this international symposium has encouraged the presentation of different experiences, in various areas of training within organizations. Taking them as stepping stones, participants shed light on the emergence of new conceptual and methodological knowledge for taking action in organizations.

Following her conference in the context of the Projectique symposium organized by ESTIA, Bidard, in September 2018, on the theme "Work on the test of complexity", we've invited Professor Nicole Saliba-Chalhoub, a specialist in applied psychoanalysis and hermeneutics, to share with us, through a paper, her vision of the concept of work through hermeneutics. The paper shows in particular the heritage and the anchoring of Judeo-Christian mythology in the notion of work. In this wake, the hermeneutic grid makes it possible to understand the notion of work through the triptych God - Work - Man. Work is seen as the way for men to gain their originally lost power. This incessant quest, explains Nicole Saliba-Chalhoub, corresponds to the structuring that has guided men for three millennia. And this is further extended through the notion of artificial intelligence, apprehended today as the displacement of the previously mentioned triptych where the divine is replaced by artificial intelligence in order to understand the relationship between the individual and the work. In the end, the paper sheds an original light on the notion of work and shows the importance of multidisciplinary approach to tackle complex notions like this one.

In this first issue of Projectics 2019, readers are also invited to discover five papers dealing with various topics related to the complexity of organizations and the renewed insight to address them.

The contribution of Marie-Noëlle Albert, Nadia Lazzari Dodeler and JeanPierre Perouma revolves around social innovation in light of the concept of community of people. The authors show that social innovation can be understood in the light of people who are affected by this innovation, hence the need to organize these people in community in order to innovate. In the following paper, Fana Rasolofo-Distler shows her interest in performance management and more specifically through Corporate Social Responsibility (CSR). By mobilizing the Actor-Network-Theroy, she shows the need for a dialogue between management control and organizational strategy, between short and long terms. The paper written by Serge Simen and Diane Ebene Nkoa addresses the issue of Human Resource Management in Very Small Enterprises (VSEs) in Africa. They put forward a complex notion, in this case, solidarity and especially the cultural values of solidarity to promote innovative HRM methods. The paper of Pavaree Suriyantphupha and Michael Bourlakis, visiting professor at IAE Metz - School of Management, offers a review of the literature to show the complexity of the relationship between information technology and retail supply chain. Their results show that inter-organization is the node of this relationship with the aim of reducing time and costs. The last paper is an opinion note proposed by Nadège Ingrid Gouanlong Kamgang. She is interested in the necessity of managing databases to better understand and compare the complexity of managerial practices in African companies.

Have a good reading of this first issue of 2019 ! 